\title{
Research on the Equity Compensation System of Venture Entrepreneurs
}

\author{
Pingping Liu \\ Beijing Wuzi University \\ Beijing, China \\ pingpl@163.com
}

\begin{abstract}
There are asymmetric information and moral hazard problems between entrepreneurs and venture capitalists. In order to effectively reduce these problems caused by uncertainty, the paper analysis on the entrepreneur's equity compensation system. It concretes from the following three aspects: entrepreneur's compensation plans, human capital and property rights and stock options. First, because venture business has a larger human capital investment, there is no mandatory information disclosure requirement and it has the poor homogeneity of the information. The entrepreneur's compensation plan is an effective means of alternative monitoring and inspiring entrepreneurs. Secondly, entrepreneur's human capital investment is a special kind of "specific investment". Entrepreneur's human capital because of its property rights characteristic and physical capital have with the same ownership, control over the right of disposal and usufruct. At last, stock option incentive mechanism can link the long-term growth of the enterprise value and the utility function of risk entrepreneurs. And thus it makes the incentives of entrepreneurs and venture capitalists more compatible.
\end{abstract}

Keywords-Venture Entrepreneurs; Equity Compensation; Human Capital and Property Rights; Stock Options

\section{INTRODUCTION}

There is a high degree of uncertainty risk in venture capital firms. And venture capital firms are facing many management, technology and market complex issues. There are serious information asymmetry and moral hazard problems between principal--venture capitalists and agents--venture entrepreneur. And it makes difficult to supervise agents. Moreover, the interests of non-complete consistency between venture capitalists and venture entrepreneur makes it possible to agent for their own interests at the expense of the interests of the principal. Therefore, we must establish an effective compensation mechanism to regulate the conduct of operations of the agents and ensure that operators do not deviate from profit maximization goals. Thus entrepreneurs can start from the self-serving motives to make the interests of the client actions. And it meets the interests of clients and entrepreneurs in the interests of mutually compatible.

\section{VENTURE ENTREPRENEUR'S COMPENSATION PLAN}

In the governance process of venture capital firms, management control undoubtedly plays an important role.
However, the premise of monitoring is that behavior of agent can be observed and verifiable. The actual situation is not fully possessing. First, compared with the traditional enterprise, in the early of venture capital firms, the human capital investment of venture entrepreneur are more and their behaviors can't be observed and the low verifiability. Thus it makes more difficult to monitoring. Second, unlisted companies do not have mandatory disclosure requirements and entrepreneurs more than investors have information advantage [1-3]. If entrepreneurs are not actively, relying on the contract, the investor is difficult to collect comprehensive, accurate and timely information. Third, venture capital firms are highly specialized and poor homogeneity of the information. Thus it is difficult to manage and monitor. Therefore, agent theory is that when monitoring difficulties and the cost is too large, the entrepreneur's compensation plan is effective means of alternative monitoring and inspiring entrepreneurs.

In venture capital firms, entrepreneurs' compensation (fixed salary, equity and stock options) is linked with the corporate performance. The basic wage is significantly lower than non-venture-backed companies [4-6]. Entrepreneurs give up the stability of higher wages and join the entrepreneurial activity full of risks. In addition to the pursuit of success and the feeling of accomplishment, from revenue perspective, but also to the pursuit of higher returns in the future. Most of the benefits of entrepreneurs are the form of stock options. Through these long-term incentives, entrepreneurs and investors' interests tend to agree, which can effectively reduce the moral hazard of the entrepreneur. Through measures during the exercise period of stock gradually granted and Increased loss of opportunity to entrepreneurs and other management leaving, so as to achieve the purpose of attract and retain talent. Stock option is the reform of property rights and incentive ways in the enterprise especially venture capital firm due to the increasingly important role of human capital. This change makes the traditional corporate governance model to face challenges. That is to say in monetary capital to the separation of ownership and management as the basis, to monetary capital owners and operators how to define the relationship between content of tradition management pattern, to the money capital and the manpower capital as the basis, with the two kinds of capital in relation to the coordination center for theoretical model. 


\section{HUMAN CAPITAL AND PROPERTY RightS}

Adam Smith's classical economic growth theory has been thought that the rate of accumulation of capital is the main driving force of economic development. Until the 1950s of last century, Solow's economic growth theory pointed out that technological progress is the main driving force of economic growth. Solow's production function serving technological progress as an exogenous variable and public goods that obviously does not match reality. Since the 1980s, Romer's new theory of economic growth serves technological progress as an endogenous variable, emphasizing the importance of knowledge. And he thinks that innovation based new combination of existing knowledge is a major force for promoting economic growth. Knowledge can be infinite instead of a loss due to the spillover of knowledge and replicable. And the marginal effect of increasing compensates for the diminishing marginal benefit resulting from the increase of labor and capital inputs. Romer's new growth theory is essentially reflects the importance of people as carriers of knowledge.

Investment in human capital is different from physical capital investment[7,8]. Entrepreneurs' human capital investment is a special kind of "specific investments". It not only has the general characteristics of the human capital, but also because of the nature of labor, the risks and social status of different. As the core elements of business management, the value of its capital is somewhat different. He is not only the product of a family investing to natural persons, but also the product of the social evaluating on natural persons. Therefore, the value of entrepreneurial human capital is both the capitalization of the human element and the Capitalization of the personality factors.

People's view on the important role of human capital in production and human capital need to stimulate this issue is consistent with each other $[9,10]$. But they have different views on human capital with business ownership. In this paper we believe that: entrepreneurs' human capital liking physical capital creating the remainder of the enterprise, and highly specialized human capital of entrepreneurs, the inseparability of their owners and the relatively low liquidity of it have the nature of the collateral, and thus it takes the risk and it should be entitled to claim and control power. Property rights characteristics of human capital and inherent incentive requirements will undoubtedly have a major impact on the corporate governance. But the above ownership arrangements for the governance model "capital employs labor" and "labor employs capital" are the two extreme cases. And they are also rare in real life. Currently the dominance of them is "capital employs labor". But with the rising of the role and status of human capital owners and their bargaining position of the corporate governance process growing, the traditional "capital employs labor" model will be challenged. Therefore, the owner of the physical capital and human capital owners to governance will become the main model of the future governance model in venture capital firms.

Property characteristic of entrepreneur's human capital and physical capital have ownership, control power, disposal and usufruct right[11,12]. In the market economy, they are two equal interests and ownership bodies. However, the natural attribute of entrepreneurial human capital determines human capital also has the particularity of its non-separated from its carrier. The owners of human capital's will and behavioral factors impact on when, where and the manner in which the use of human capital. When he felt that the use of human capital does not meet the will, its efficiency will be greatly reduced or even negative effect. Therefore, the incentive of human capital is particularly important, especially property rights incentive[13,14]. The importance of human capital in enterprises, especially in high-tech enterprises has become a consensus knowing. Human capital owned property right of enterprises is also an indisputable fact [15]

\section{STOCK OPTIONS}

From the management point of view, there are three incentives: the first is a positive incentive, the second is a reverse incentive, and the third is the promised incentives for certain behavior, increasing the opportunity cost of this action, so as to achieve the incentive purpose. Stock option is in this way to encourage entrepreneurs and management teams to work hard. When the company's profit increase and stock prices rise, some option value will increase substantially; the contrary, they may be nothing.

The residual claim of entrepreneurs given by venture capitalists is in the form of stock options. It is the option that option owners buy the company shares or stock at the agreed price in the future. Compared with other motivational tool such as fixed salaries, bonuses and jobs upgrade, the maximum incentive effect of stock options is it closely links the enterprise value of the long-term growth to venture entrepreneurs' utility function. It makes the enterprise performance to the important variable of venture entrepreneur's income function. And then venture entrepreneurs are no longer just focus on short-term financial targets, but rather focus more on long-term benefits and sustainable development of enterprises. Thus makes the incentive of venture entrepreneurs and venture capitalists are more compatible[16,17]. In many high-tech venture companies, stock options are not limited to management and key technical personnel and even extended to all employees. As we pointed out, venture capital firm is more like a production team. In this team, there are multiple agency relationship, such as principalagent relationship between senior managers and general staff. Therefore, senior managers not only need to inspire, general staff also need to motivate. Stock option incentive system will be extended to all employees, thus it can ensure that their goals could create the most value for the venture enterprise.

Venture capital firm has the characteristics with high risk and high return, its success relies heavily on venture entrepreneur. In Schumpeter's view, a person was willing to engage in innovation, because he saw a profitable opportunity to bring innovation. Whether high-tech venture is successful or failure, it depends largely on the driving force of innovation within the enterprise, and the size of the driving force behind innovation in turn depends to some extent on the business of distribution system[18,19]. For the high-tech venture capital companies, stock options are more incentive than internal shareholding system. Stock options make the entrepreneur's expectations to build on through their own efforts to make 
businesses succeed, improve efficiency and enhance the share price. It connects the operators compensation with corporate performance and development together to form a long-term incentive and restraint mechanisms of risk managers and owners, and maximize the value of venture capital firm[20,21].

From the perspective of entrepreneur's human capital property, stock option is not only an incentive problem, but also further recognize property rights of human capital, admit human capital and physical capital having equal status to create wealth[22,23]. Venture entrepreneurs with human capital owned by them should have a residual claim business. With the development of economy and society, and constantly enrich material wealth, the leading role of human capital in economic development continues to strengthen. Human capital, especially entrepreneurs' human capital is more scarce and important, entrepreneurial human capital is more advantage than physical capital in the game process[24,25]. Entrepreneurs with their business skills, enjoy the operating surplus is an inevitable trend.

\section{REFERENCES}

[1] Liu Pingping, Study on the operational mechanism theory of venture capital---Based on contract mechanism and human capital perspective. Peking: Uni. of International Business and Economics Press, 2009.

[2] De Clercq, D., Sapienza, H. J. Effects of relational capital and commitment on venture capitalists perception of portfolio company performance. Journal of Business Venturing,2006,21:326 347

[3] Liu, M. M. H., Zhang, J. A., Hu, B., Domestic VCs versus foreign VCs: A close look at the Chinese venture capital industry, International Journal of Technology Management, 2006,34(1-2):161 184

[4] Baker, M., and Gompers,P A. An analysis of executive compensation, ownership and control in closely held firm,working paper, 1999.

[5] Mike Wright, Venture capital in China:A view from Europe, Asia Pacific Journal of Management,2007

[6] Cumming, D., Contracts and exits in venture capital finance, Mimeo., University of Alberta,2002

[7] Ducker, P. F., Innovation and entrepreneurship, New York: Harper Row, 1985

[8] Grossman, G., E. Helpman, Innovation and growth in the global economy, Cambridge: MIT Press, 1991

[9] Chen, X.-P., Eberly, M. B., Chiang, T.-J., Farh, J.-L., \& Cheng, B.-S. (2014). Affective trust in Chinese leaders: Linking paternalistic leadership to employee performance. Journal of Management, 40(3), 796-819.
[10] Schlösser, O., Frese, M., \& Heintze, A.-M. (2014). Human orientation as a new cultural dimension of the GLOBE Project: A validation study of the GLOBE scale and out-group humane orientation in 25 Countries. Journal of Cross-Cultural Psychology, 44(4), 535-551.

[11] Weiss, H. M., \& Cropanzano, R. (1996). Affective events theory: A theoretical discussion of the structure, causes and consequences of affective experiences at work. In B. M. Staw and L. L. Cummings (Eds.), Research on organizational behavior (Vol. 18, pp. 1-74). Greenwich, C.T.: JAI Press.

[12] Wang, H., Law, K. S., \& Chen, G. (2008). Leader-member exchange, employee performance, and work outcomes: An empirical study in the Chinese context. International Journal of Human Resource Management, 19, 1809-1824.

[13] [13]Rafaeli, A., \& Sutton, R. I. (1989). The expression of emotion in organizational life. In L. L. Cummings and B. M. Staw (Eds.), Research in organizational behavior (Vol. 11, pp. 1-42). Greenwich, C.T.: JAI Press.

[14] Wang, H. (2008). Leadership behavior in organization. Beijing: Peking University Press.

[15] Gray Becker. Human capital. Peking: China Citic Press, 2007.

[16] Li Shichun. Venture capital investment in USA: course, mechanism and revelation. Research on economics and management, 2007,8.

[17] Avnimelecha G., Teubalb M., Creating venture capital industries that coevolve with high-tech: Insights from an extended industry life cycle perspective of the Israeli experience. Research Policy,2006,35(10):1477 1498

[18] Dimov, D., Shepherd, D. A., and Sutcliffe, K.M. Requisite expertise, firm reputation, and status in venture capital investment allocation decisions. Journal of Business Venturing,2007,22:481 502

[19] Lerner ,J., Venture capitalists and the decision to go public, Journal of Financial Economics, 1994,35(3):293 316

[20] Liu Pingping, Jiang Chunsheng. A Design of the Incentive and Restraint Mechanisms for Venture Capitalists in the Venture Funds of the Limited Partnership,2014 International Conference on Global Economy, Commerce and Service Science,2014.

[21] Liu Pingping. Theory and demonstration analysis on venture capitalists deployment intellectual capital, 2011 international conference on education science and management engineering,2011.

[22] OECD, Venture capital and innovation. OCDE/GD,1996,168

[23] Parhankangas, A., Landstrom, H. How venture capitalists respond to unmet expectations: The role of social environment, Journal of Business Venturing,2006, 21(6):773 801

[24] Ahlstrom D., Bruton G.D., Venture capital in emerging economies: Networks and institutional change. Entrepreneurship Theory and Practice,2006,30(2):299 320

[25] Liu Pingping. Study on Internal Endowment of Entrepreneurial Team, 2011 International conference on information, services and management engineering, 2011. 